\title{
Contribuições do Nedet para a gestão social no Território Rural do Sudoeste Goiano
}

\author{
Divina Aparecida Leonel Lunas \\ Universidade Estadual de Goiás \\ Hamilton Matos Cardoso Júnior \\ Instituto Federal de Educação Ciência e Tecnologia de Mato Grosso
}

\section{Resumo}

Desde o ano de 2013 as universidades públicas brasileiras passaram a participar do planejamento, execução, monitoramento e avaliação da política do desenvolvimento territorial rural no Brasil por meio da criação, pelo Ministério do Desenvolvimento Agrário, dos Núcleos de Extensão em Desenvolvimento Territorial - Nedets. Este trabalho traz um relato das estratégias, experiências e contribuições do Nedet do Território Rural do Sudoeste Goiano, coordenado pela Universidade Estadual de Goiás e financiado pelo referido Ministério, para a gestão social nesse Território no âmbito da política do desenvolvimento territorial rural. Pretende-se, desse modo, trazer um relato dos avanços observados pelo Nedet no âmbito técnico e metodológico dentro do Colegiado Territorial assessorado. Traçam-se análises sobre as atividades desenvolvidas no Colegiado e nos Comitês Temáticas das Mulheres e dos Jovens. Para isso, elegeu-se a seguinte metodologia: revisão bibliográfica e documental; realização de trabalho de campo e análise das informações coletadas. Destaca-se que as ações do Nedet contribuíram para garantir a gestão social no Território, resgatando a representatividade, incentivando o empoderamento e a participação dos sujeitos do campo no planejamento, controle e avaliação da política pública.

Palavras-chave: Colegiado. Desenvolvimento Rural. Nedet. Território.

\section{The Contributions of Nedet to Social Management in the Rural Territory of Southwest Goiano}

\begin{abstract}
Since the year of 2013, Brazilian public universities began to participate in the planning, implementation, monitoring and evaluation of rural territorial development policy in Brazil. For this, the Ministry of agrarian development created Territorial Development Extension Nuclei - Nedet. This work brings an account of strategies, experiences and Nedet contributions on the rural territory of Southwesthern Goiás, coordinated by the State University of Goiás and funded by the Ministry of Agricultural Development
\end{abstract}


- MDA, for the social management and the collaborative development of this territory in the framework of territorial rural development policy. It is intended, therefore, to verify the advances on the technical and methodological framework that Nedet promoted under the advised Territorial Collegiate. Trace analysies on the activities carried out in the Territorial Collegiate and Thematic Chambers for Women and Youth. Thus, the following methodology was applied: bibliographical and documental reviewing; performing fieldwork and collected information analysis. Worth to point out that Nedet actions contributed to ensuring social management in the territory, enforcing representation, encouraging empowerment and participation of stakeholders on the planning field, control and evaluation of public policy.

Keywords: Collegiate. Rural Development. Nedet. Territory.

\section{Contribuciones del Nedet para la Gestión Social en el Territorio Rural del Sudoeste Goiano}

\section{Resumen}

Desde el año 2013 las universidades públicas brasileñas han participado en la planificación, ejecución, seguimiento y evaluación de la política de desarrollo territorial rural en Brasil. Para ello, se creó el Ministerio de desarrollo agrario de los núcleos de extensión en el desarrollo territorial - Nedet. Este trabajo aporta una explicación de las estrategias, experiencias y contribuciones de la Nedet del territorio rural del suroeste de Goiás, coordinada por la Universidad Estatal de Goiás y financiada por el Ministerio de desarrollo agrario, para la gestión social y para la Desarrollo colaborativo en esta área en el contexto de la política de desarrollo territorial rural. Por lo tanto, se pretende verificar los avances en el marco técnico y metodológico que dicha Nedet alentó en la Colegiata territorial asistida. Se elaboran análisis sobre las actividades desarrolladas en las cámaras universitarias y temáticas de mujeres y jóvenes. Para ello se eligió la siguiente metodología: revisión bibliográfica y documental; Realización del trabajo de campo y análisis de la información recolectada. Cabe destacar que las acciones de Nedet contribuyeron a asegurar la gestión social en el territorio, redimiendo la representatividad, fomentando el empoderamiento y la participación de los sujetos de campo en la planificación, control y evaluación de la política pública.

Palabras-Clave: Colegiado. Desarrollo rural. Nedet. Territorio.

\section{Introdução}

Este trabalho tem como objetivo realizar um relato das estratégias, ações e experiências do Nedet do Território Rural do Sudoeste Goiano, no período de 2015 a 2017, para efetivar a gestão social. Traçam-se análises sobre as atividades desenvolvidas no Colegiado de Desenvolvimento Territorial - Codeter e nos Comitês Temáticas das Mulheres e dos Jovens.

As recentes estratégias do governo federal para o desenvolvimento territorial rural no Brasil têm apostado na inserção das Universidades como instituições atuantes no assessoramento dos Territórios Rurais e da Cidadania. Para isso, foram criados Núcleos de Extensão em Desenvolvimento Territorial - Nedet nos Territórios Rurais e da Cidadania. Assim, as universidades passaram a coordenar esses núcleos, participando do planejamento, execução, monitoramento e avaliação da política no nível dos Territórios.

Dentre as atividades extensionistas que as Universidades devem desenvolver por meio dos Nedets, está o assessoramento à gestão social. Essa gestão deve estar 
pautada na inserção dos diferentes atores sociais do campo na política do desenvolvimento territorial, oferecendo uma importante característica a essa política: assegurar às diferentes instâncias da sociedade a participação no planejamento das ações territoriais, combinando a dinâmica dos interesses no campo em agendas discutidas e implantadas coletivamente.

Sendo assim, a gestão social nos Territórios baseia-se na operacionalização da política territorial de forma horizontal, superando o aspecto vertical das políticas e chamando a atenção da sociedade para a participação no processo de desenvolvimento rural, incentivando a gestão social participativa, bem como a gestão dessa participação nos Territórios.

A Universidade Estadual de Goiás, em parceria com o Instituto Federal Goiano, é uma das instituições públicas que passou a integrar essa política. Desde o ano de 2015, tem desenvolvido ações de assessoramento, por meio do Nedet, no Território Rural do Sudoeste Goiano (Estado de Goiás).

Do ponto de vista dos objetivos aqui elencados, a pesquisa foi desenvolvida de forma exploratória, envolvendo o levantamento bibliográfico e técnico sobre a temática, bem como qualitativa, descrevendo as experiências obtivas pelo Nedet nas atividades de gestão social.

Foram aplicados os seguintes passos metodológicos: pesquisa bibliográfica sobre os conceitos de território, gestão social e sobre a política do desenvolvimento territorial; análise de documentos governamentais produzidos pelo extinto MDA; realização de trabalho de campo, etapa desenvolvida durante as ações extensionistas do Núcleo pela qual foi possível aplicar questionários, coletar dados, realizar entrevistas e produzir relatórios, e análise qualitativa das informações coletadas. As atividades do Nedet no referido Território ocorreram no período de 2015 a 2017.

O artigo está dividido em cinco seções a contar com esta introdução. Desse modo, na segunda seção, são trabalhados os objetivos da política do desenvolvimento territorial, bem como apresentado o Território Rural do Sudoeste Goiano e a criação do seu respectivo Nedet. A terceira seção destaca o conceito de gestão social e seu papel para a efetivação da política dos Territórios. Na quarta seção, subdividida em duas subseções, são apresentados as ações e os desafios do NEDET para efetivar a gestão social no âmbito do Codeter do Território Rural do Sudoeste Goiano, bem como para a criação e manutenção dos Comitês no Território. Por fim, a quinta e última seção apresenta as considerações finais a respeito da discussão aqui realizada.

\section{Abordagem territorial e o Nedet do Sudoeste Goiano}

Durante o breve período de existência do extinto MDA (1999-2016), suas políticas públicas para a superação das desigualdades no campo estiveram focadas na abordagem conceitual do desenvolvimento territorial e a esfera regional foi vista como potencializado do desenvolvimento rural no País. Os recortes regionais abarcam um conjunto de municípios que são denominados e reconhecidos como um Território Rural ou da Cidadania e são fundamentais para a participação dos agricultores nas políticas públicas do governo (CARDOSO JÚNIOR; LUNAS; GOMES, 2017). 
A extinta Secretaria de Desenvolvimento Territorial - SDT, integrante da estrutura do MDA, a partir do ano de 2004, foi o órgão central responsável por homologar e prestar assessorias aos Territórios Rurais e da Cidadania no Brasil. Ficava resguardado a essa secretaria o papel de operar e consolidar a abordagem do desenvolvimento territorial rural sustentável no País ${ }^{1}$ (CARDOSO JÚNIOR; LUNAS; GOMES, 2017).

Conforme Dantas e Costa (2014), os Territórios são instâncias institucionalizadas e organizadas em torno de um Colegiado Territorial. Nessas instâncias, as deliberações acerca do investimento de recursos de políticas públicas devem ser tomadas por decisão da maioria por meio de votação. Para os autores:

\begin{abstract}
os territórios rurais foram criados como uma forma de estratégia para que se possam integrar os espaços rurais visando os aspectos sociais, econômicos e políticos. O objetivo dessa construção é identificar os territórios a partir da composição de identidades regionais. É claro que em alguns estados do Brasil, tais territórios foram ajustados para responder a outras divisões estabelecidas. (DANTAS; COSTA, 2014, p. 830).
\end{abstract}

Portanto, os Territórios Rurais, bem como os Territórios da Cidadania², são importantes instâncias destinadas ao planejamento territorial e ao processo do desenvolvimento territorial sustentável no campo. Representam a descentralização das decisões e incentivo à autogestão das políticas públicas.

Até o ano de 2015, o Brasil possuía um total de 258 Territórios homologados. Desse total, 123 eram Territórios Rurais e 135 estavam inseridos como Territórios da Cidadania. A Região Nordeste era a que mais abarcava Territórios, com um total de 104, seguida pelas regiões Norte, com 43 Territórios instituídos, Centro-Oeste, com 42, Sul, com 40 e Sudeste, com 29. No Estado de Goiás existiam, até essa data, 12 Territórios, sendo 8 Rurais e 4 da Cidadania (PORTAL DOS NEDETS, 2017).

A partir de 2013, a consolidação da abordagem territorial para 0 desenvolvimento rural teve a inserção das universidades como parceiras da SDT nesse processo. Segundo a SDT (2015), as universidades públicas estão presentes em grande parte dos Territórios Rurais e da Cidadania. Nesse sentido, reconhecendo a importância da discussão acadêmica, a SDT procurou incluir as instituições públicas de ensino superior por meio da criação dos Nedets.

O projeto dos NEDETs iniciou-se no ano de 2013 e foi constituído por duas etapas: 1) Projeto-piloto 2013 - universidades com renomado conhecimento no desenvolvimento territorial foram convidadas a implantar os Nedets. Nessa primeira etapa, foram aprovados 10 projetos que abrangiam 56 territórios; entretanto, somente 9 projetos foram contratados, correspondendo a 51 territórios em 8 estados brasileiros; 2) Chamada Pública 2014 - realização de parcerias com as universidades púbicas para a implantação de Núcleos nos Territórios restantes por meio de edital e seleção de propostas apresentadas à SDT.

\footnotetext{
1 Com as mudanças governamentais ocorridas no ano de 2016, a política do desenvolvimento territorial perdeu sua característica setorial devido à extinção do MDA e suas secretarias, passando a integrar as ações da Casa Civil por meio da Secretaria Especial de Agricultura Familiar e do Desenvolvimento Agrário

2 São definidos entre os Territórios Rurais com piores condições e indicadores socioeconômicos que merecem políticas públicas específicas para a superação dessa realidade.
} 
A ação de parceria com as Universidades foi financiada pelo MDA em conjunto com o Conselho Nacional de Desenvolvimento Científico e Tecnológico CNPq. Segundo a SDT (2015) os Núcleos tinham como objetivo geral:

\begin{abstract}
contribuir para a consolidação da abordagem territorial como estratégia de desenvolvimento sustentável para o Brasil Rural e da articulação das políticas públicas integrantes da matriz do Programa Territórios da Cidadania, por meio da articulação institucional e operacional de Universidades Públicas Federais e Estaduais, dos Institutos Federais de Educação Tecnológica, das instâncias de gestão social dos Territórios Rurais e da Secretaria de Desenvolvimento Territorial. (SDT, 2015).
\end{abstract}

Além da parceria com o CNPq, também participaram do projeto a Secretaria de Políticas para as Mulheres e a Diretoria de Políticas para as Mulheres Rurais, ambas integrantes da estrutura do extinto MDA. Segundo o Portal dos Nedets (2017), foram apoiados 239 Territórios $^{3}$, divididos entre 119 Territórios Rurais e 120 Territórios da Cidadania, abrangendo 3.568 municípios (64,3\% do total do País), englobando mais de 76 milhões de habitantes no País. A duração dos projetos totalizava 24 meses (2015-2016).

Os projetos eram propostos e coordenados por professores efetivos das universidades. Dentro da estrutura dos Núcleos, além do coordenador, estão os Assessores Territoriais de Gestão Social - ATGS, os Assessores Territoriais de Inclusão Produtiva - ATIP e os Assessores Territoriais de Gênero - ATG.

Além do objetivo geral, apresentado anteriormente, os Nedets possuíam como objetivos específicos: assessorar os Colegiados Territoriais; apoiar as atividades definidas na agenda dos Territórios; difundir métodos e tecnologias voltadas à gestão social da política territorial; produzir dados, informações e conhecimentos por meio de pesquisas; assessorar e articular a participação das mulheres, jovens, comunidades tradicionais e outros grupos sociais nos Colegiados Territoriais e apoiar a consolidação dos Territórios Rurais e da Cidadania (SDT, 2015).

Tendo em vista que a integração entre o desenvolvimento rural e a abordagem territorial como objeto das políticas públicas do MDA, entende-se que a alavancagem das ações destinadas ao campo necessita da integração entre as universidades e a comunidade.

A promoção de ações de extensão e pesquisa com foco na implementação e apoio aos Núcleos de Desenvolvimento Territorial visou à diminuição das desigualdades e exclusões recorrentes do modelo de crescimento econômico do estado de Goiás e mesmo do País. Em atendimento ao edital de chamada pública CNPq/MDA/SPM-PR N 11/2014, foi proposto o projeto "Implantação e manutenção de núcleos de extensão em desenvolvimento territorial em Goiás - Território Rural Sudoeste Goiano" sendo este aprovado pelo CNPq com duração de 24 meses (2015/2016), prorrogado até julho de 2017, possuindo como entidade proponente e executora a Universidade Estadual de Goiás - UEG.

O projeto de extensão teve como objetivo geral: desenvolver, implementar e manter ações extensionistas e de pesquisa no Território Rural do Sudoeste Goiano (Figura 1) por meio das ações integradas a serem definidas no âmbito da política do MDA para a capacitação e a gestão social; consolidação das políticas públicas de

\footnotetext{
3 Dos 258 existente, 19 Territórios não receberam Nedets.
} 
desenvolvimento rural; e, também, pela inclusão produtiva nos territórios definidos no projeto.

Figura 1. Localização e composição do Território Rural Sudoeste Goiano, 2016

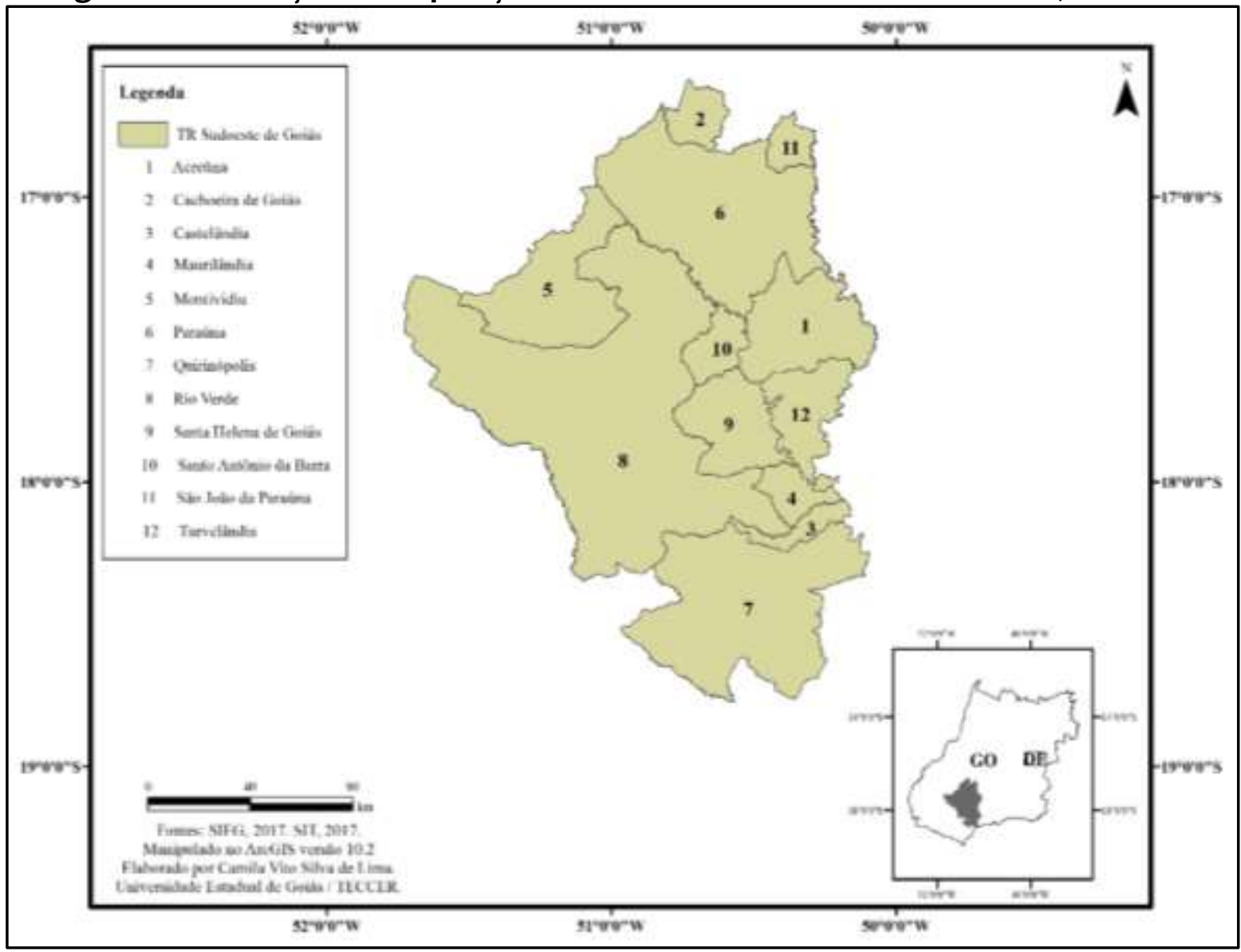

De acordo com o censo do Instituto Brasileiro de Geografia e Estatística IBGE (2017) no ano de 2010 viviam nesse Território 324.914 habitantes, sendo o município mais populoso o de Rio Verde, com uma população de 176.424 habitantes.

A atuação do Núcleo nesse Território foi definida devido à presença de unidades universitárias da Universidade Estadual de Goiás e do Instituto Federal Goiano, essenciais no apoio ao desenvolvimento de ações de extensão, o que permitiu uma atuação direta em seus municípios.

Entre as atividades desenvolvidas pelo NEDET do Sudoeste Goiano esteve a criação e o desenvolvimento de atividades que contribuíssem para o mapeamento e avaliação das políticas implementadas nesse Território e para a capacitação e qualificação, por meio de conferências, dias de campo, palestras e oficinas, dos agentes para a promoção do desenvolvimento rural sustentável.

\section{Gestão social na Política do Desenvolvimento Territorial}

Para Paula (2005), os processos de gestão social ganham contornos mais nítidos com a redemocratização e descentralização das políticas públicas no Brasil. Esse processo permite a inclusão de temas nas políticas públicas até então 
ignorados pelo governo, bem como permitem a criação de espaços públicos para a participação e controle (SANTOS; AVRITZER, 2002).

De acordo com Abramovay (2005), o principal desafio institucional da política pública do desenvolvimento territorial rural é cunhar condições de inserção dos sujeitos do campo, diretamente ou indiretamente beneficiados, nas discussões sobre os rumos das ações tomadas em âmbito local para a concretização do processo do desenvolvimento rural.

Essa política focou em áreas de resultados que direcionaram o planejamento de suas ações. De acordo com Echeverri (2010), foram quatro áreas de concentração. A primeira teve como objetivo fortalecer a gestão social dos Territórios. Essa área tem como visão a gestão da participação coletiva, do compartilhamento entre os atores sociais dos Territórios, empoderamento e incentivo à participação social. Para isso:

[...] é imprescindível a criação institucional de instâncias colegiadas e de processos de planejamento participativo que se traduza em verdadeiros pactos sociais que envolvam os atores sociais desde as suas demandas concertadas $\mathrm{e}$ os agentes públicos desde sua oferta articulada. (ECHEVERRI, 2010, p. 92).

A segunda área de resultado teve como foco o fortalecimento das redes de organizações sociais. Sendo assim, reconhece-se nos Território Rurais a existência de uma complexidade de atores sociais com realidades distintas, sendo a participação social fonte essencial para a operação de uma política dessa natureza. O capital social é visto, desse modo, como um ativo central nos Territórios “[...] incorporando as redes de cooperação, a criação de confiança para a ação coletiva a integração das organizações de atores e a solidez dos compromissos e acordos obtidos entre eles" (ECHEVERRI, 2010, p. 92).

A terceira área definida para resultados busca o modelo da dinamização da economia local. Para isso, busca-se a prioridade no tratamento das potencialidades dos Territórios, reconhecendo o desenvolvimento pela perspectiva endógena. Ações para a criação de associações e cooperativas, bem como fortalecimento das cadeias produtivas dos Territórios enquadram-se como centrais para a inclusão produtiva.

Por fim, a quarta área de resultados da política territorial tem como objetivo fortalecer a articulação da política pública nos Territórios, fortificando as redes institucionais públicas para a efetivação dos programas governamentais para a agricultura familiar, entendendo que "[...] umas das maiores virtudes do enfoque de Território é o de aportar uma visão integral dos componentes e dinâmicas econômicas e sociais, assim como os dos aspectos ambientais, culturais e políticos" (ECHEVERRI, 2010, p. 93).

A gestão social tem sido definida por diferentes autores para compreender a garantia dos direitos dos cidadãos. Para Kauchakje (2007, p. 27), gestão social pode ser entendida como a "[...] gestão de ações sociais públicas para o atendimento de necessidades e demandas dos cidadãos, no sentido de garantir os seus direitos por meio de políticas, programas, projetos e serviços sociais". As políticas públicas concretizam a garantia dos direitos e servem como ferramentas de ação do Estado 
para atender aos interesses e às necessidades da sociedade (COHEN; FRANCO, 2007).

Fischer (2002) ainda acrescenta que a gestão social pode ser conceituada como:

[...] um processo de mediação que articula múltiplos níveis de poder individual e social. Sendo um processo social e envolvendo negociação de significados sobre o que deve ser feito, por que e para quem, a gestão não é uma função exercida apenas por um gestor, mas por um coletivo que pode atuar em grau maior ou menor de simetria/assimetria e delegação, o que traz uma carga potencial de conflito de interesse entre atores envolvidos e entre escalas de poder (FISCHER, 2002, p. 27).

Nesse sentido, a autora evidencia que há uma complexidade no interior da gestão social, definindo esse processo como algo coletivo e que não está livre das relações de conflito. A gestão social não é um conceito que abarca a atuação de apenas um gestor, mas da sociedade. Essa gestão está ligada a distintas dimensões como a econômica, política, ambiental, dentre outras. Todavia, Kliksberg (1996) afirma que a prática da gestão social ainda é frágil na macroestrutura do setor público, tendo em vista que possui influência limitada no âmbito de grandes decisões.

O autor supracitado ainda sustenta que o tratamento inferior dado à política da gestão social pode ser responsabilizado, de certo modo, pela manutenção e reprodução dos problemas sociais no Brasil. Koga (2003, p. 23) ainda afirma que "este tratamento subalterno dado ao âmbito das políticas sociais públicas brasileiras tem resultado na crescente mercantilização dos serviços tidos como básicos à população".

Para Kliksberg (1998), a gestão social deve ser encarada como ação essencial para a transpor da ideia de que apenas o crescimento econômico será necessário para a superação das desigualdades no País. É necessário englobar a população nesse processo, integrando-a também nas decisões que lhe afetam diretamente nos diversos setores, incentivando e permitindo o planejamento, o controle e a avaliação de políticas públicas. O autor defende que a gestão social deve ter sua própria agenda de gerenciamento.

A prática da gestão social sinaliza para a construção do conceito de "cidadania deliberativa", definindo como importante a criação de espaços coletivos que permitam ao indivíduo a participação nas políticas públicas, onde a sociedade passa a ter a possibilidade de assumir uma postura mais ativa nas ações do Estado (TENÓRIO, 1998). Esses espaços fornecem, segundo Evans (2003, p. 23) “[...] bases mais sólidas para avaliar as prioridades de desenvolvimento, [...] dando aos cidadãos a oportunidade de exercer a capacidade humana fundamental de fazer escolhas".

Portanto, a gestão social é uma ação complexa e desafiadora que articula a garantia dos direitos através da ação de políticas públicas que considerem a participação da sociedade com o papel do Estado, que abdica da decisão monopolizada, em sua forma organizacional que considere o novo status dado à área social na tendência de torná-la como central, expandindo, dessa forma, a noção de desenvolvimento social.

A gestão social é uma prática social que pressupõe a organização da sociedade, de forma mais ampla e incisiva, no âmbito do Estado para a participação 
no processo de construção e tomadas de decisões. Ela permite ampliar a transparência e as ferramentas que permitem a participação, materializando-se na consolidação de espaços públicos que consolidem as redes público-comunicativas entre sociedade e Estado.

Dessa maneira, esses novos espaços que permitem a gestão social devem ser criados com o intuito de credenciá-los não como simples espaços que irão gerir/operar recursos públicos, mas de modo que reconheçam as dinâmicas sociais do local. Devem ser consolidados como espaços capazes de permitir a reconhecer as capacidades e potencialidades produtivas endógenas, bem como a ampliação da participação dos diferentes atores sociais envolvidos na condução das políticas públicas e na promoção do desenvolvimento. Essa concepção de gestão que vem sendo defendida por uma revisão das teorias de desenvolvimento, que, segundo Evans (2003, p. 30),

[...] começou a se desviar do "fundamentalismo do capital", primeiramente enfatizando a "tecnologia", e posteriormente, o papel das ideias que de forma mais geral enfocam as instituições. Esse movimento reforçou a convicção de que a qualidade de instituições básicas de governança deveria ser considerada o elemento chave para fomentar $o$ crescimento.

A SDT define a gestão social como "[...] uma certa maneira de gerir assuntos públicos, neste caso em particular as políticas e iniciativas voltadas à promoção do desenvolvimento dos espaços rurais" (BRASIL, 2003, p. 11). O MDA (BRASIL , 2005) ainda entende gestão social como:

[...] processo através do qual o conjunto dos atores socais do território se envolve não só nos espaços de deliberação e consulta das políticas para o desenvolvimento, mas sim e mais amplamente, no conjunto de iniciativas que vão desde a mobilização desses agentes e fatores locais até a implementação e avaliação das ações planejadas, passando pelas etapas de diagnóstico, de elaboração de planos, de negociação de políticas e projetos. (BRASIL, 2005, p. 10).

Desse modo, para que essa gestão ocorra, o MDA (BRASIL, 2005) prevê que, na abordagem territorial do desenvolvimento rural, é imprescindível que sejam estabelecidas nos Territórios articulações sociais em rede entre os agentes públicos e privados para o fortalecimento de institucionalidades de descentralização e compartilhamento das decisões. Como se observa na citação anterior, há sobre a gestão social nos Territórios a preocupação com um olhar que focalize a ação participativa dos atores envolvidos relacionada à mobilização para o planejamento, acompanhamento e avaliação da política pública.

Nessa abordagem de gestão e desenvolvimento, o capital social presente nos Territórios assume papel de relevância. "Os processos de gestão social precisam, para tanto, se apoiar no capital social dos territórios, nos laços de identidade, de confiança e de colaboração que há entre as forças locais" (BRASIL, 2005, p. 10). Para o MDA (BRASIL , 2005), o capital social é entendido como:

[...] o conjunto de relações (pessoais, sociais, institucionais) que podem ser mobilizadas pelas pessoas, organizações e movimentos visando a um determinado fim, o capital social tem na sua raiz processos que são, a um 
só tempo, baseados e geradores de confiança, reciprocidade e cooperação. (BRASIL, 2005, 9).

O capital social dos Territórios implica na habilidade das pessoas e dos grupos, organizados pelas novas institucionalidades de gestão social, em estabelecerem relações efetivas que permitam a gestão dos recursos financeiros, materiais, cognitivos e informacionais disponíveis no Território e fora dele e que são vitais para a condução da política do desenvolvimento territorial. Segundo o MDA (BRASIL, 2005), esse capital pode manifestar-se de três formas: capital social de grupos e indivíduos; capital social de comunidades; capital social externo.

São os espaços de gestão social apoiados no capital social dos Territórios que podem afiançar as ações criadas para o alcance do desenvolvimento rural, aglutinando e sustentando os fatores locais e permitindo a participação dos atores sociais na condução dos planos da política pública, bem como permitindo o engajamento e mobilização de iniciativas desenhadas para que, gradualmente, possa-se alcançar a desejada melhoria na qualidade de vida no meio rural, superação das desigualdades e efetivação da cidadania.

Na política do desenvolvimento territorial o espaço que permite a gestão social é notadamente o Codeter. Dentro desse colegiado, são criados outros espaços que garantam a participação e a gestão social como: os Núcleos Técnicos, as Plenárias e os Comitês Temáticos.

Portanto, de modo geral, a gestão social pode ser definida como um processo no qual o Estado inclui a sociedade civil nos atos de planejar, traçar diretrizes, ações e tomar decisões voltadas ao desenvolvimento e ampliação da produção de riquezas locais. Assim sendo, a gestão social é uma ação política e deliberativa, na qual os diferentes atores sociais participam nas decisões e destino da sociedade (PAULA, 2005).

\section{Ações do Nedet do Território Rural do Sudoeste Goiano para a gestão social}

\subsection{Experiências com o Codeter do Sudoeste Goiano}

Em busca do alcance das áreas de concentração de resultados definidas pelo MDA, sob os princípios da representatividade, pluralidade e diversidade, os Codeter, criados nos Territórios, assumem papel como eixo central para a implementação das ações destinadas ao desenvolvimento rural e gestão social. Os colegiados podem ser definidos como comissões ou espaços destinados à participação coletiva e que devem ter como responsabilidade a gestão social de políticas e de programas de desenvolvimento rural nos Territórios Rurais e da Cidadania.

Esses espaços "oportunizam o diálogo, a negociação, a aprendizagem, a transparência e a democracia necessária à construção de um ambiente favorável à integração e ao estabelecimento de consensos, de acordos, ações e compromissos coletivos fundamentais ao processo de desenvolvimento" (BRASIL, 2009, p. 4).

Nesse sentido, tendo em vista as áreas de resultados definidas pela política, o Nedet do Sudoeste Goiano concentrou suas ações iniciais no entendimento da dinâmica do Colegiado do Território Rural do Sudoeste Goiano. Como resultado dessa primeira observação, os principais desafios encontrados diziam respeito à 
reestruturação da representatividade no Colegiado Territorial e ao fortalecimento institucional dessa instância no Território.

De acordo com o Regimento Interno do Território Rural do Sudoeste Goiano (2010), o colegiado é organizado pela Plenária, Núcleo Diretivo e Núcleo Técnico. No início das atividades do Nedet observou-se uma fragilidade da representatividade da sociedade civil, das mulheres e dos jovens nessas estruturas organizacionais, tendo em vista que representantes do poder público compunham a maioria no Colegiado Territorial, bem como havia a ausência de representantes de alguns dos municípios. Esse contexto não permitiria a operacionalização da política, bem como efetivação da participação já que "os movimentos sociais em geral têm resistência em se aproximar do poder público para discutir o território e a gestão compartilhada das infraestruturas" (FLORISBELO, 2005, p. 81).

O Colegiado do Território Rural do Sudoeste Goiano é composto por quatro representantes de cada município, dois efetivos e dois suplentes, sendo que cada município elege, por meio de plenária, dois representantes para compor o Núcleo Diretivo (REGIMENTO INTERNO, 2010). Quando o Nedet iniciou suas atividades, no ano de 2015, oito dos onze municípios possuíam representatividade no Colegiado Territorial.

Esse contexto de sobreposição da representatividade do poder público, bem como a ausência de mulheres e jovens no colegiado, ia de encontro às diretrizes das políticas públicas bem como do próprio Regimento Interno (2010), no qual se afirma que: "O Território Rural do Sudoeste Goiano terá caráter paritário em relação às entidades da sociedade civil (Estado/Sociedade Civil)" (REGIMENTO INTERNO, 2010, p. 1). À época, os representantes do poder público totalizavam $60 \%$ do total de integrantes do colegiado, e a sociedade civil $40 \%$.

De acordo com Ortega (2015), por meio da criação dos Territórios Rurais, o Estado atua como um ator auxiliar na política do território, transferindo aos Colegiados Territoriais o papel de decisão sobre quais áreas e projetos os recursos das políticas públicas serão aplicados ${ }^{4}$. Essas decisões deverão ser tomadas por meio de um processo de discussão coletiva e participativa de todos os envolvidos no contexto do Território, definindo-se, dessa forma, agendas de prioridades a serem seguidas na condução dos investimentos públicos. Nesse contexto, observou-se a emergência de ações que incentivassem os agricultores, integrantes das associações e sindicatos, às mulheres e, ainda, os grupos específicos, como os jovens, a participar das discussões no âmbito do Território.

Tendo como direcionamento o caráter paritário na participação do Colegiado Territorial do Sudoeste Goiano, as diretrizes da política do desenvolvimento territorial e as áreas de concentração de resultados definidas pelo MDA, o NEDET do

\footnotetext{
${ }^{4}$ Entretanto, inúmeras reflexões analíticas produzidas no âmbito da série Desenvolvimento Rural Sustentável do Instituto Interamericano de Cooperação para Agricultura - IICA demonstram que o poder de decisão das instâncias dos colegiados quanto aos recursos a serem aplicados bem como a sua efetiva aplicação esbarra em diversas particularidades da política territorial, dentre elas: a falta de institucionalidade do Território. No pacto federativo brasileiro, os recursos públicos somente podem ser repassados aos entes públicos como municípios, Estados e União. Dessa maneira, embora a participação e controle social exercidos no âmbito dos Colegiados Territoriais sejam responsáveis pelo empoderamento dos atores sociais envolvidos no processo e, em alguma medida, estes espaços tenham participado através do debate, pactuação e proposição de projetos coletivos, vale destacar os distintos graus de institucionalidade dos Codeter.
} 
Sudoeste Goiano procurou definir ações na reestruturação do Colegiado Territorial. Foram realizadas visitas às prefeituras que não possuíam participação, reforçando a importância da indicação de representantes para o colegiado. Do mesmo modo, foram reforçadas, também por meio de visitas, as relações entre o Nedet, o Território e as prefeituras que já possuíam representantes ativos.

Traçada e aplicada essa primeira ação, buscou-se, por meio do diálogo com a comunidade, incentivar sua participação nos espaços de discussão, tendo em vista a necessidade de dar nova credibilidade à política pública por meio da mobilização, negociação e organização territorial incentivando a participação da sociedade civil no Colegiado Territorial. Um desses momentos pode ser observado na Figura 2, que traz uma das plenárias ocorridas no ano de 2017.

Figura 2. Plenária Realizada no Município de Santa Helena de Goiás, 2017

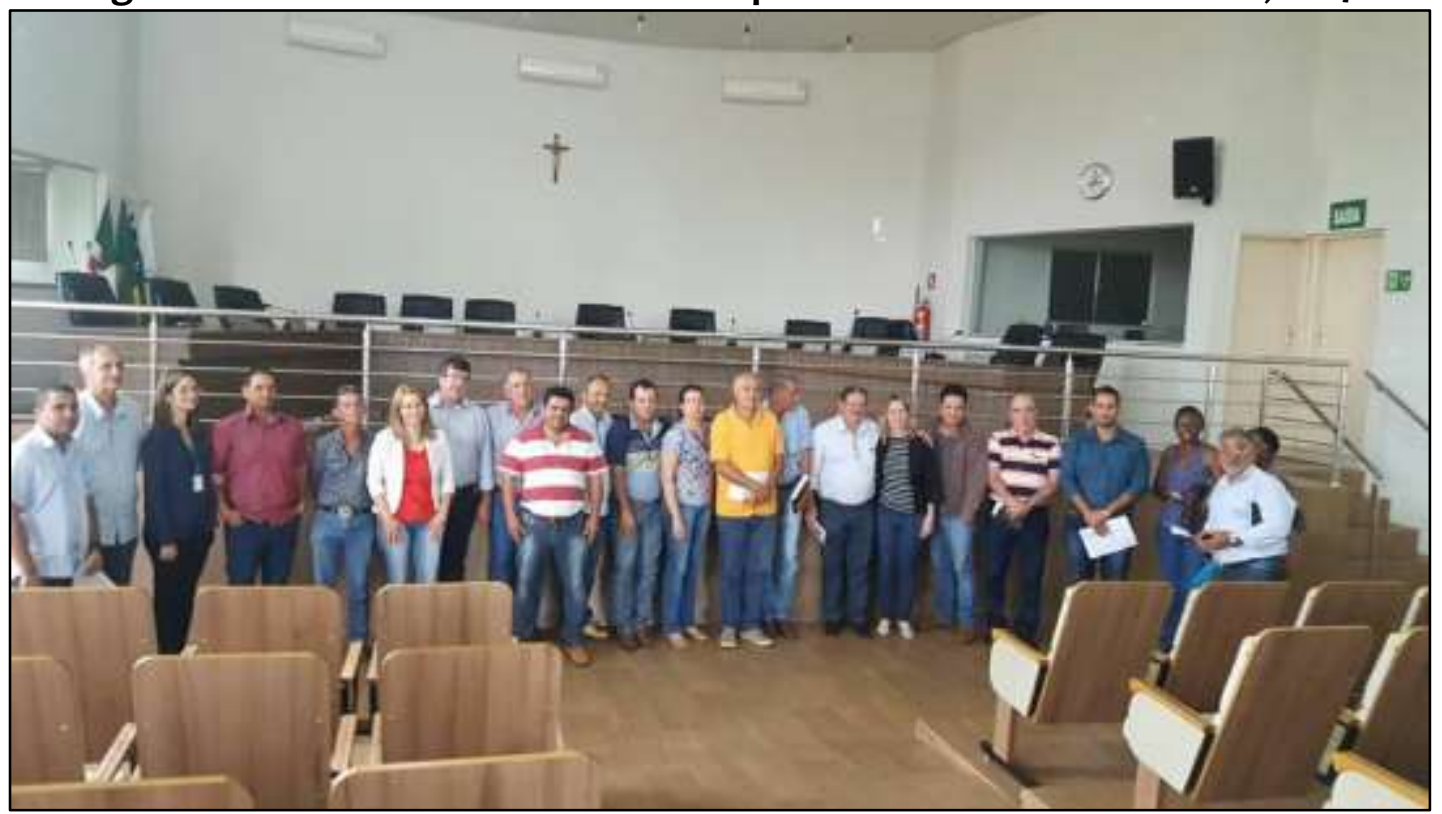

Fonte: Acervo do NEDET do Sudoeste Goiano (2017).

Após as ações do Nedet, pôde-se observar aumento na participação da sociedade civil nas plenárias. Ao final do projeto, em 2017, dez dos onze municípios têm representantes no colegiado. A distribuição da representatividade da sociedade civil passou a ser de $60 \%$ do total dos integrantes, observando-se, também, o aumento no número de mulheres.

O fato da composição do colegiado ser, após as ações do NEDET, predominantemente da sociedade civil não invalida esse espaço de discussão. Conforme 0 artigo $4^{\circ}$ inciso I da Resolução $\mathrm{n}^{\circ} 48$ do Conselho Nacional de Desenvolvimento Sustentável - Condraf, de 16 de dezembro de 2004, a composição desses espaços de discussão deve contemplar:

I - que, no mínimo $\mathbf{5 0 \%}$ (cinquenta por cento) das vagas sejam ocupadas por representantes de entidades da sociedade civil organizada, que representem a agricultura familiar, estudem ou promovam ações voltadas para seu apoio e desenvolvimento (movimentos sociais, entidades sindicais, cooperativas e/ou associações produtivas, comunitárias, entidades de assessoria técnica e organizacional, etc); II - que, no máximo 
$\mathbf{5 0 \%}$ (cinquenta por cento) das vagas sejam ocupadas por representantes do poder público (executivo, legislativo ou judiciário), vinculadas ao desenvolvimento rural sustentável (inclusive universidades), de organizações de caráter para-governamental (tais como: associações de municípios, sociedades de economia mista cuja presidência é indicada pelo poder público, entre outros) e de outros setores da sociedade civil organizada não diretamente ligados à agricultura familiar (como empreendedores rurais dos setores de serviços e industrial). (CONDRAF, 2004, negrito nosso).

Nesse sentido, não há disposição contrária à maior participação da sociedade civil em espaços de discussão coletiva, como é o caso dos Colegiados Territoriais, destinados às ações para o desenvolvimento rural sustentável. Como afirmado anteriormente, outro desafio que mobilizou ações do Nedet diz respeito ao resgate da institucionalidade do Colegiado Territorial, ou seja, o seu reconhecimento como a base da organização institucional do Território. Pôde-se observar, durante visitas aos assentamentos, fazendas e associações, que havia um descrédito com as políticas relacionadas ao governo federal, bem como quanto ao papel do colegiado.

Em virtude desse Território não ter recebido nenhum assessoramento desde sua criação por parte do governo, sendo o NEDET a primeira ação desse tipo, aliado com a desigual distribuição na representatividade do colegiado até aquele momento, observou-se que as instâncias colegiadas ainda não haviam conseguido se estruturar de forma efetiva para gerir as ações do Território.

Nesse contexto, também foram definidas ações juntamente com o colegiado para o desenvolvimento de estratégias relacionadas à articulação das ações territoriais e à mobilização dos atores e entidades no Território. Essas ações estiveram relacionadas à visita aos sindicatos, associações, cooperativas, assentamentos rurais e às propriedades rurais para divulgação e explicação da política do desenvolvimento territorial, do papel do Território, do colegiado, bem como da importância da participação efetiva do homem/mulher do campo nas discussões coletivas. Para isso, foram produzidos folhetos explicativos (Figura 3), bem como definida uma agenda de plenárias que comtemplassem todos os municípios do Território. 
Figura 3. Folder de divulgação da política do desenvolvimento territorial no Sudoeste Goiano - Goiás, 2015

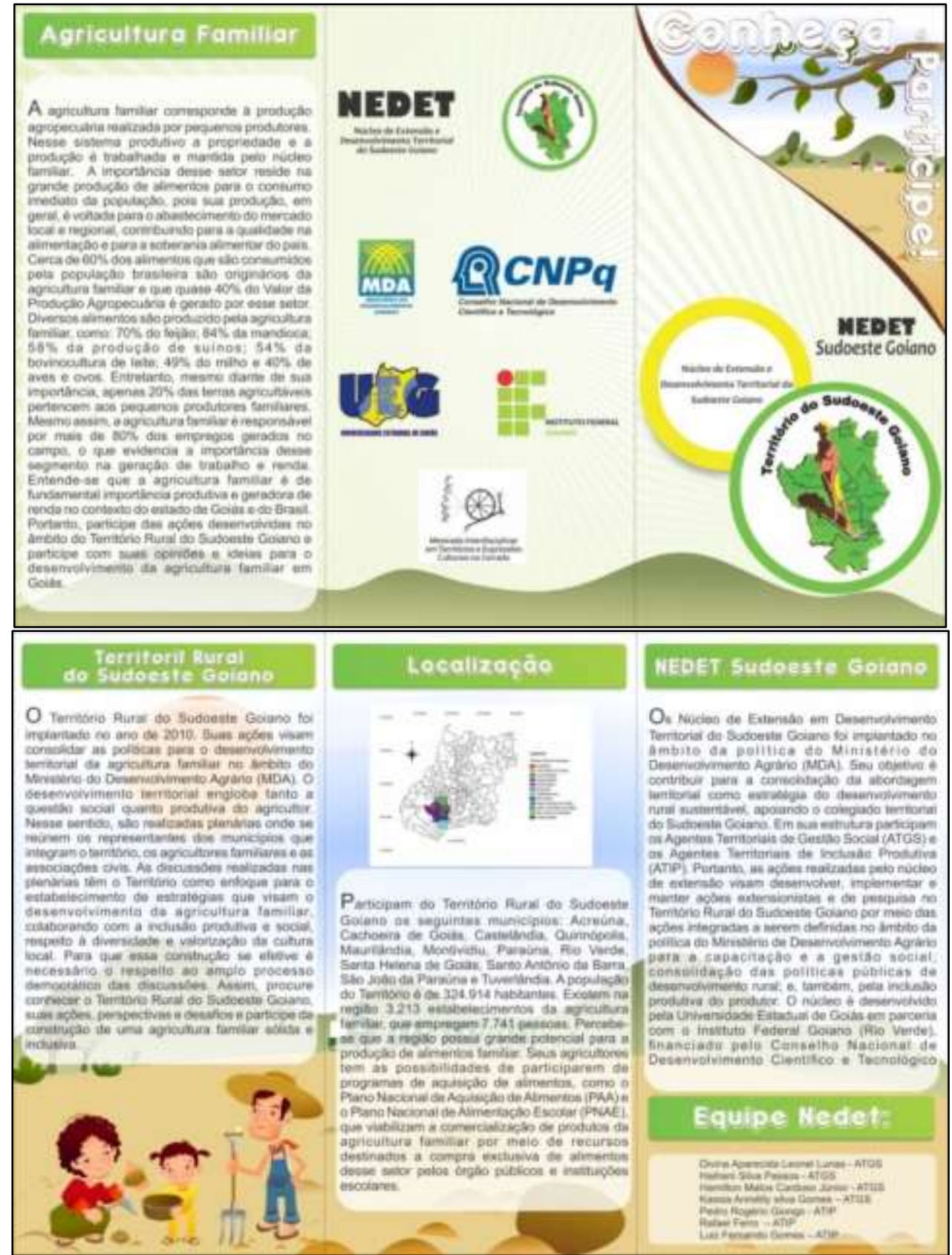

Fonte: Acervo do Nedet do Sudoeste Goiano (2015).

Por meio dessas ações, buscou-se ainda minimizar os problemas de interlocução observados entre representantes e representados, o que causava danos à gestão social da política. Havia falta de diálogo e até mesmo de interações entre os atores locais, muitas vezes desencadeadas pela falta de conhecimento das diretrizes e objetivos da política, bem como do papel de cada um na dinâmica das discussões e decisões coletivas.

Ressalta-se que a presença de recursos públicos para apoio à política foi de suma importância para as ações do Nedet, visando organizar a logística das reuniões do Colegiado Territorial. Por meio das diárias e subsídios ao deslocamento 
dos atores sociais, foi possível mobilizar e incentivar a comunidade e os representantes a participarem das reuniões e dos espaços de decisões, fomentando, dessa forma, a cidadania no Território, bem como a definição de uma agenda de reuniões que percorresse todos os municípios que participam do colegiado.

As ações do NEDET com os integrantes do Colegiado Territorial e demais atores sociais sempre foram realizadas por meio de trabalho de campo e participação nos espaços coletivos. Os principais pontos debatidos giram em torno da sensibilização para o fortalecimento da participação na consolidação da política publica, pensando sua gestão por meio da prática social, da participação e governança como meios indispensáveis para o empoderamento do homem/mulher do campo, resultando na aproximação entre as instituições governamentais e a sociedade.

Além das ações de reestruturação do colegiado e da representatividade; gestão dos recursos destinados à logística das reuniões e fortalecimento da institucionalização do Colegiado Territorial, o NEDET do Sudoeste Goiano ainda atuou nesta instância por meio das seguintes ações: assistência metodológica às reuniões do Núcleo Diretivo e Plenárias; assessoria técnica na elaboração de projetos que foram submetidos a editais do governo federal, a exemplo do Programa de Apoio à Infraestrutura nos Territórios Rurais - PROINF; produção de material de divulgação da política e do Território; apoio na elaboração, cumprimento e monitoramento da agenda de ações do colegiado; auxílio na organização de eventos do Território destinados às mulheres, jovens, bem como à inclusão produtiva, dentre outros.

\subsection{Experiências e criação dos Comitês Temáticos}

A Resolução $\mathrm{n}^{\circ} 52$ de 16 de Fevereiro de 2005, do Condraf, em seu artigo $4^{\circ}$, afirma que: "A institucionalidade territorial deverá ser composta em função dos atores presentes no território, levando-se em consideração o art. $4^{\circ}$ da Resolução $n^{\circ} 48$ do CONDRAF, devendo ainda contemplar as questões de gênero, raça, etnia e geração na sua composição" (CONDRAF, 2005).

Portanto, observa-se que a ideia de gestão social nos Territórios Rurais e da Cidadania, definida pela política do desenvolvimento territorial, considera a necessidade de inclusão dos diferentes atores sociais no desenvolvimento rural. Para isso, é necessário incluir as mulheres, os jovens, as comunidades tradicionais e outros grupos em busca de minimizar as barreiras à participação e controle social da política. Considera-se que essa ação deve ser efetivada por meio do empoderamento desses atores sociais.

O empoderamento deve contribuir para fortalecer as novas institucionalidades trazidas pelos Territórios, expressando formas mais avançadas para garantir a governança nesses espaços e aperfeiçoando as relações estabelecidas entre o Estado, o Território e a Comunidade (BRASIL, 2005, p. 11).

Ao iniciar suas atividades em 2015, o NEDET do Sudoeste Goiano identificou a não existência de espaços destinados à discussão de questões específicas relacionadas à mulher rural, ao jovem no campo, à raça, gênero ou etnias. Portanto, para atender às metas da política territorial, elegeu-se como uma de suas 
prioridades a inserção dos jovens e das mulheres nos espaços de discussão.

Destarte, realizou-se uma revisão dos deveres e obrigações na institucionalidade territorial, atribuindo, formalmente, novos papéis e atribuições a esses atores socais por meio da criação de dois Comitês Temáticos na estrutura do Colegiado Territorial: o das Mulheres e o dos Jovens. Por meio do apoio da gestão social desses novos espaços, esperava-se enfatizar a convergência dos interesses desses diferentes grupos para articulação das ações do Colegiado Territorial.

Dois motivos levaram o Nedet a dar prioridade a esses grupos. Primeiro, devido à importância da mulher na economia rural local e na luta pela terra no Território Rural do Sudoeste Goiano. Observou-se a existência de arranjos produtivos organizados pelas mulheres, como é o caso da fabricação de panificados no Assentamento Jenipapo, Município de Acreúna, bem como o destaque da mulher na luta pela regularização fundiária dos lotes no Assentamento Ponte de Pedra, Município de Paraúna, que há mais de 20 anos espera regularização pelo Instituto Nacional de Colonização e Reforma Agrária - Incra (LUNAS et al., 2017).

Há, portanto, a necessidade da superação da visão patriarcal direcionada à mulher do campo, tendo reconhecida sua importância no processo do desenvolvimento rural. A respeito disso, Cisne (2015) afirma que é necessário perceber a mulher rural como um sujeito político e superar a ideologia da naturalização do sexo. Daí a necessidade do Comitê Temático enquanto um espaço político institucionalizado que leve à criação de uma consciência política da mulher no processo de afirmar-se como um agente de transformação social perante a sociedade.

Segundo, em virtude do reconhecimento da importância do jovem no campo para assegurar a sociedade rural e dar continuidade às atividades agrícolas familiares. A falta de políticas direcionadas aos jovens do campo tem contribuído para o envelhecimento da população do mundo rural, tendo em vista que procuram nas cidades oportunidades que lhes foram negadas no campo, como: formação básica, profissionalização, acesso ao crédito e emprego. Portanto, torna-se oportuno o apoio ao Comitê Temático dos Jovens no Território como um ambiente para a inserção dos jovens como protagonistas na política do desenvolvimento territorial.

O Comitê Temático das Mulheres (Figura 4) foi criado no dia 22 de novembro de 2015, em plenária realizada durante a II Conferência Nacional da Assistência Técnica e Extensão Rural - ATER no município de Quirinópolis/Goiás. Composta apenas por mulheres que totalizam atualmente cinco integrantes. 
Figura 4. Reunião do Comitê Temática das Mulheres no Município de Paraúna Goiás, 2016

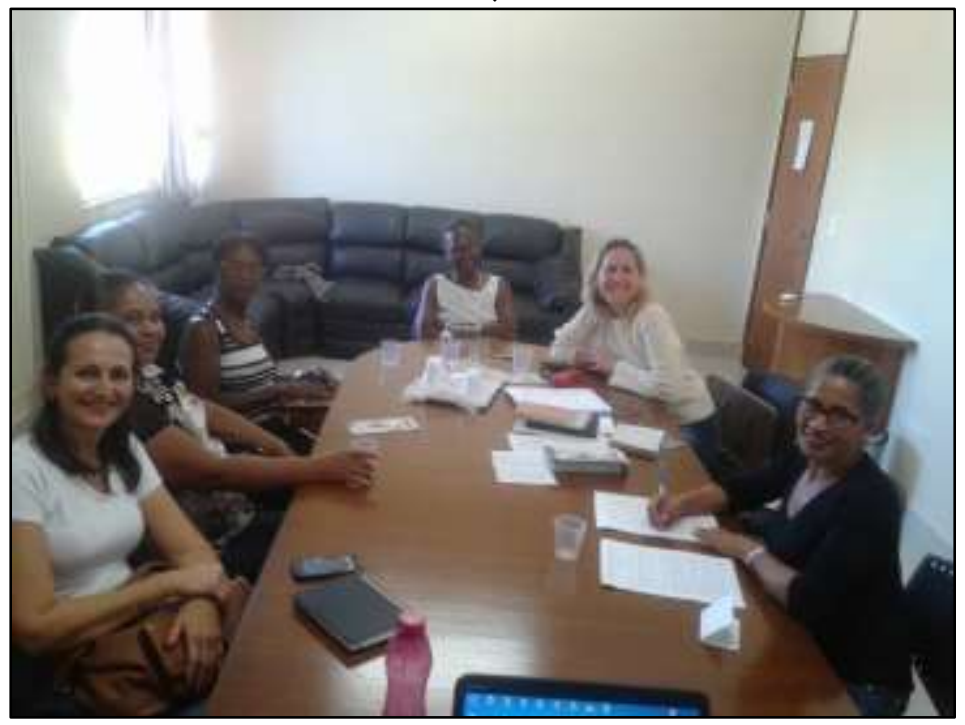

Fonte: acervo do Nedet do Sudoeste Goiano (2016).

Esse espaço tem por objetivo a integração da mulher rural, criando momentos com reuniões e discussões que possam promover a socialização de problemas comuns, despertar a importância da representatividade feminina para o desenvolvimento da agricultura familiar, inclusão produtiva com valorização e apoio ao gênero feminino.

Criou-se, dessa forma, um espaço no qual o Nedet do Sudoeste Goiano pôde identificar e apoiar as iniciativas produtivas e de comercialização já em operação no Território, bem como incentivar a participação do gênero nas plenárias com intuito de que possam participar das decisões relacionadas à aplicação de recursos públicos de programas governamentais.

Visando à inclusão produtiva da mulher no campo, o Nedet do Território Rural do Sudoeste Goiano assessorou na elaboração de um projeto destinado à estruturação da feira do Assentamento Ponte de Pedra, Município de Paraúna, submetido ao edital do Proinf Mulher 2016.

Como ação do Comitê Temático das Mulheres, foi realizada, no dia 02 de abril de 2016, a "I Conferência Territorial da Mulher do Sudoeste Goiano". O evento ${ }^{5}$ teve como objetivos: realizar um encontro entre as mulheres do Território para a troca de experiências; divulgação dos produtos produzidos pelas mulheres (alimentos, hortaliças, artesanatos, dentre outros); realização de rodas de conversa com temas pré-determinados; e promoção de momentos de bem-estar para a mulher do campo.

A proposta da Conferência esteve baseada no empoderamento da mulher como ator social ativo do campo, enfatizando o conhecimento da sua realidade e a convergência de interesses desse grupo no Território para a elaboração de uma

\footnotetext{
${ }^{5}$ Vale destacar que a realização desta conferência fazia parte de uma estratégia da SDT/MDA/SPM no âmbito da organização da 4 a Conferência Nacional de Políticas para as Mulheres realizada em maio de 2016.
} 
agenda que pudesse conduzir e articular as ações do Comitê Temático das Mulheres.

A Conferência foi dividida em dois momentos principais: no primeiro, com a abertura do evento e acolhida das participantes; momento de beleza e bem-estar; abertura da feira; e exposição dos produtos artesanais das mulheres rurais. Em seguida, aconteceu a abertura do evento (Figura 5), com debate entre as mulheres rurais, momento no qual estiveram presentes representantes do MDA, quando foram expostas as políticas públicas para as mulheres rurais, seus acessos e limites.

Figura 5. Abertura da I Conferência Territorial da Mulher do Sudoeste Goiano em Santa Helena de Goiás, 2016

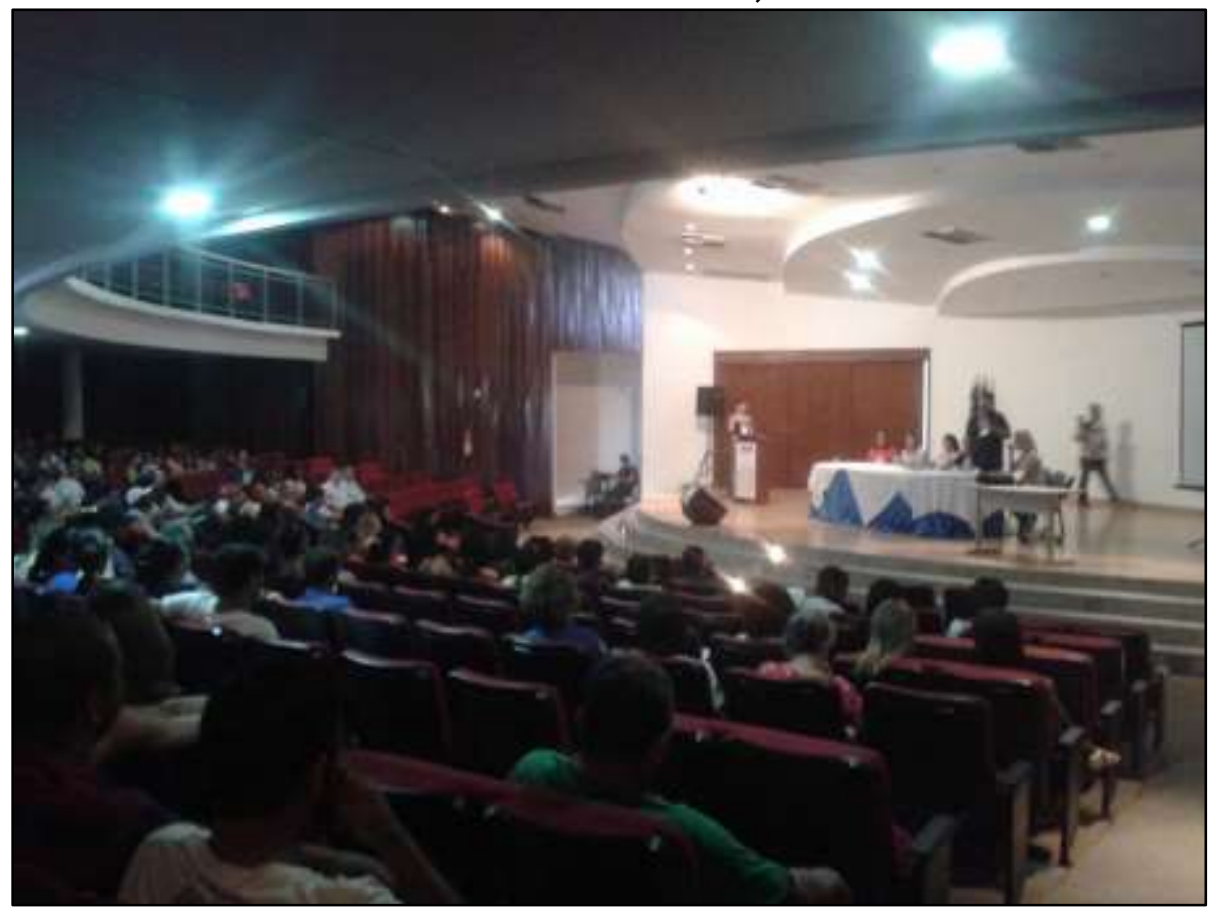

Fonte: acervo do NEDET do Sudoeste Goiano (2016).

A segunda parte da Conferência partiu da formação de mesas redondas para as mulheres rurais com os temas: cooperativismo e associativismo para a Organização das mulheres; violência contra a mulher no campo e na cidade e agroindústria e bovinocultura para agricultura familiar. A formação dessas mesas possibilitou conversas e informações acerca dos temas acima.

O evento ainda buscou proporcionar a visualização das transformações do Território pelas ações das políticas públicas e investimentos voltados para a mulher rural brasileira.

Considera-se o evento de grande importância para a revitalização da representatividade feminina no Colegiado Territorial, bem como para o reforço das conquistas e direitos sociais das mulheres rurais. O evento, além da socialização e integração da mulher rural, serviu de base para algumas reflexões que nortearam as ações do NEDET no Território Rural do Sudoeste Goiano para a continuidade do projeto. Ao final, foi elaborada uma carta aberta das mulheres que participaram do evento, na qual constam suas necessidades e perspectivas. 
Com relação aos jovens, foi criado o Comitê Temático dos Jovens. Esse espaço de discussões teve como objetivo integrar a juventude do Território Rural do Sudoeste Goiano à política do desenvolvimento territorial, apreendendo suas expectativas, necessidades e ideias. O Comitê foi composto em sua integralidade por jovens residentes em assentamentos rurais.

Durante as reuniões realizadas, pôde-se perceber que a principal demanda dos jovens no Território Rural do Sudoeste Goiano estava relacionada à oferta de cursos de ensino superior e profissionalizantes que estivessem voltados à sua realidade. De acordo com os jovens, são poucas ou quase nenhumas as oportunidades para a profissionalização no campo. Após completarem o ensino médio, necessitam migrar para outros municípios em busca do ensino superior. Os que ficam na zona rural não conseguem profissionalizar-se e têm o trabalho braçal como principal atividade.

Infelizmente, essa é uma realidade brasileira. Os jovens rurais são colocados à margem do desenvolvimento no País e excluídos das novas oportunidades, gerando a evasão desses indivíduos do campo. A respeito disso, Mello (2006) afirma que são três os motivos que geram a evasão no campo, principalmente nos assentamentos de reforma agrária: 1) a conjuntura familiar (mão de obra insuficiente); 2) as políticas públicas que não conseguem ser acessadas pelos jovens, o que reflete a falta de incentivo do governo a sua permanência no campo; 3) a ausência de conhecimento agrícola.

A evasão desses indivíduos do campo traz sérias consequências para o espaço rural. Como afirma Santos (2006), à medida que os jovens do campo deixam seu espaço de origem, há uma perda nas relações de produção, que sustentam a agricultura familiar, base da alimentação no Brasil. Há prejuízo para a tradição camponesa, para a mão de obra, valores sociais e culturais.

Portanto, a evasão traz um alerta importante para as reflexões a serem feitas no âmbito do Comitê Temático dos Jovens. Observa-se que as possibilidades para modificar a realidade presente no Território estão aliadas à inserção dos jovens na política do desenvolvimento territorial, buscando, por meio do trabalho coletivo, inserir as demandas desses atores sociais no colegiado. Considera-se que a não inserção dos jovens nesse processo torna sem fundamento as ações para o desenvolvimento rural, tendo em vista que os jovens são os indivíduos que darão continuidade às ações voltadas ao desenvolvimento da agricultura familiar, sendo de suma importância sua permanência no meio rural.

Nesse sentido, foi definida uma agenda de ações do Comitê, estruturada nas seguintes ações: realização de reuniões periódicas com os jovens; participação do Comitê em eventos voltados ao jovem no campo para posterior disseminação das informações obtidas (Figura 6); apoio para a criação de cursos superiores com base na pedagogia da alternância ${ }^{6}$.

\footnotetext{
${ }^{6}$ Essa última ação visou a parceria com a Universidade Estadual de Goiás. Para isso, foram realizadas algumas reuniões com o Comitê e demais jovens interessados na região. Ficou definida a realização de um abaixo assinado no Território que foi colhido pelos jovens e entregue na reitoria da Universidade com apoio do Nedet. O processo de viabilização do curso ainda encontra-se em andamento.
} 
Figura 6. Momento de discussão do I Colóquio da Juventude do Território Rural do Sudoeste Goiano - Paraúna, 2016

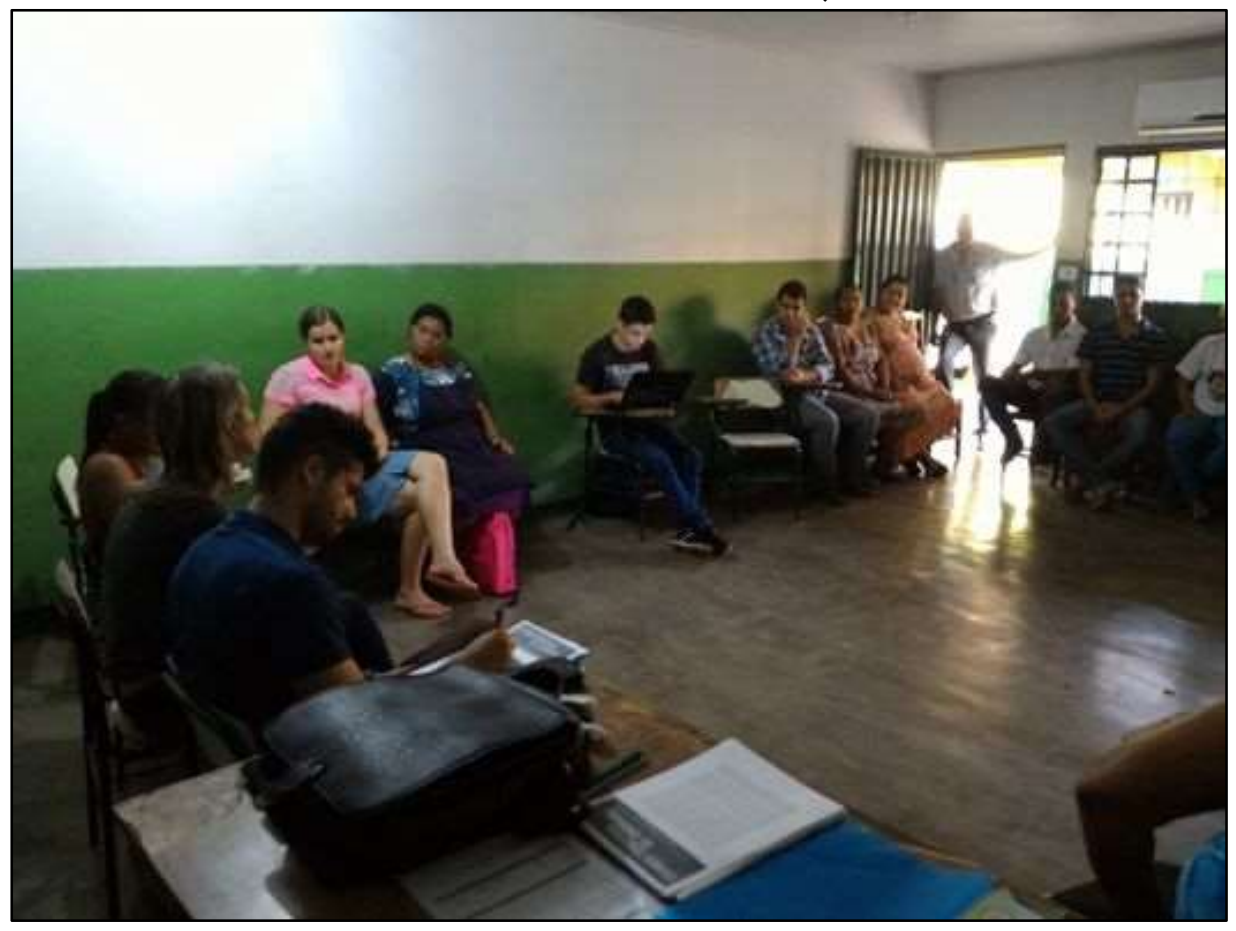

Fonte: acervo do Nedet do Sudoeste Goiano (2016).

Alguns jovens do Território, em virtude da agenda estabelecida, puderam participar do evento "Ciranda Territorial da Juventude", que ocorreu no mês setembro de 2016 na cidade de Silvânia7. No evento, puderam conhecer políticas e ações do governo destinadas aos jovens do campo. Posteriormente, as informações obtidas pelo grupo que participou (total de quatro jovens) foram disseminadas por meio das reuniões no Território e do "I Colóquio da Juventude do Território Rural do Sudoeste Goiano" (Figura 6), realizado no dia 12 de setembro de 2016 no assentamento Ponte de Pedra, no Município de Paraúna.

Considera-se que a presença do Comitê Temático dos Jovens possibilita incentivar e evidenciar o protagonismo dos jovens no Território, reconhecendo-os como sujeitos atuantes no espaço rural, bem como aceitando e trazendo para a discussão do colegiado suas necessidades e perspectivas para, por meio do tratamento específico de seus temas, traçar e colocar em prática ações que promovam a cidadania e a autonomia desses jovens no campo.

A constituição dos Comitês Temáticos, antes inexistentes no Colegiado Territorial, trouxe como experiência ao Território a descentralização interna das discussões e decisões que compunham a pauta do arranjo da política. Há uma integração de novos atores sociais, notadamente os jovens e as mulheres, o que permite gestão social da política de maneira mais efetiva e inclusiva.

\footnotetext{
7 Esse evento foi promovido pelo Território Estrada de Ferro e contou com jovens de vários Territórios Rurais e da Cidadania de Goiás. O tema do evento foi: "Sucessão e emancipação da juventude rural: caminhos e possibilidades".
} 


\section{Considerações finais}

As experiências da gestão social no Território Rural do Sudoeste Goiano mostraram desafios para a política do desenvolvimento territorial e, consequentemente, às ações do Nedet nesse Território. Os desafios giram em torno da gestão participativa e da participação no Codeter, do incentivo à sociedade civil a participar da política, o que leva à questão da representatividade, da reafirmação da institucionalidade do colegiado e de sua estrutura perante a sociedade, integração de diversos atores sociais do campo, empoderamento feminino e protagonismo dos jovens e esforço para o estabelecimento de diálogo entre representante e representado.

O contexto mais preocupante no Território estava relacionado à fragilidade existente nos laços de identidade, confiança e colaboração estabelecidos entre as forças locais. Foi nesse sentido, e em sintonia com o marco referencial do MDA, que as ações do NEDET priorizaram a criação de espaços e condições de aprendizado: que garantissem um esforço pela identificação e pelo diálogo; e que gerassem a convergência das perspectivas individuais, superando $o$ isolamento e a fragmentação do capital social nesse Território.

É importante salientar que todos os desafios encontrados, além dos citados, não puderam ser resolvidos nesses dois anos e meio de atuação do NEDET no Sudoeste Goiano. Destarte, alguns passos ainda necessitam ser tomados no rumo da efetivação do desenvolvimento territorial em Goiás. O que confirma a importância do assessoramento aos Territórios Rurais e da Cidadania, bem como da manutenção da política do desenvolvimento territorial rural.

As ações desenvolvidas pelo NEDET no Território Rural do Sudoeste Goiano contribuíram para resgatar a representatividade no Colegiado Territorial, contribuindo para atender à paridade entre poder público e sociedade civil, bem como para integrar as mulheres e os jovens nas discussões territoriais por meio dos Comitês Temáticos. Além disso, o assessoramento metodológico e técnico permitiu resgatar a institucionalidade do Colegiado Territorial enquanto espaço de discussão e deliberação coletiva no Território, reforçando a confiança dos sujeitos nessa instância.

Diante das experiências obtidas, afirma-se que a gestão social no Território deve ser realizada além das modalidades de gestão que já foram implantadas pelas políticas públicas. Por isso o termo "social" nesse tipo de gestão, já que nele há uma clara contraposição da lógica vertical e centralizada do planejamento, envolvendo e oferecendo espaços para protagonismo e envolvimento dos atores sociais locais no planejamento, implementação, acompanhamento e avaliação da política.

Por isso, reitera-se a importância da representatividade da sociedade civil no colegiado, bem como da instalação dos Comitês Temáticos como espaços de discussão de temas específicos. A inserção dos jovens, das mulheres e da sociedade civil no Território Rural do Sudoeste Goiano mostrou inegáveis avanços na condução da política, bem como na definição de agendas de ações e investimentos nesse Território. 


\section{REFERÊNCIAS}

ABRAMOVAY, R. Representatividade e inovação. In: Seminário Nacional de Desenvolvimento Rural Sustentável. Brasília: CNDRS, 2005.

BRASIL. Ministério do Desenvolvimento Agrário (MDA). Referencias para o desenvolvimento territorial sustentável (Série documentos institucionais). Brasília: CONDRAFINEAD. 2003.

BRASIL. Ministério do Desenvolvimento Agrário (MDA). Marco referencial para apoio ao desenvolvimento de Territórios Rurais (Série documentos institucionais). Brasília: SDT/MDA, 2005.

BRASIL. Ministério do Desenvolvimento Agrário (MDA). Orientação para constituição e funcionamento dos colegiados territoriais. Brasília: MDA/Departamento de gestão territorial. 2009.

CARDOSO JÚNIOR, Hamilton Matos; LUNAS, Divina Aparecida Leonel Lunas; GOMES, Deyvison Dias. A abordagem territorial para o desenvolvimento rural sustentável no Brasil. In: LUNAS, Divina Aparecida Leonel, CARDOSO JÚNIOR, Hamilton Matos; GIONGO, Pedro Rogério (Orgs.). Estado e políticas públicas no Território Rural do Sudoeste Goiano. Goiânia: Editora Kelps, 2017, p. 15-47.

CISNE, Mirla. Feminismo e liberdade no campo: a importância da organização política para as mulheres rurais. HORAS, Karla; REZENDE, Marcela; MACEDO, Gustavo (Orgs.). Coletânea sobre estudos rurais e gêneros. Brasília: MDA, 2015, p. 111-130.

COHEN, Ernesto; FRANCO, Rolando. Gestão Social: como obter eficiência e impacto nas políticas sociais. Brasília: ENAP, 2007

CONDRAF. Conselho Nacional de Desenvolvimento Rural Sustentável. Resolução $\mathbf{n}^{\circ}$ 48 do de 16 de dezembro de 2004 - Propõe diretrizes e atribuições para a rede de Conselhos de Desenvolvimento Rural Sustentável, nos diferentes níveis de atuação. Brasília: Diário Oficial da União, 2004. Disponível em: < http://www.mda.gov.br/sitemda/secretaria/condraf/resolu\%C3\%A7\%C3\%B5es>. Acessado em fevereiro de 2017.

CONDRAF. Conselho Nacional de Desenvolvimento Rural Sustentável. Resolução $\mathbf{n}^{\circ}$ 52 de 16 de fevereiro de $\mathbf{2 0 0 5}$ - Aprova recomendações do Conselho Nacional de Desenvolvimento Rural Sustentável para as Institucionalidades Territoriais de Desenvolvimento Rural Sustentável. Brasília: Diário Oficial da União, 2005.

Disponível em: <

http://www.mda.gov.br/sitemda/secretaria/condraf/resolu\%C3\%A7\%C3\%B5es >. Acessado em fevereiro de 2017. 
DANTAS, Rafaela Maximiano; COSTA, Micheli Pereira. Territórios Rurais no Brasil e suas estratégias de desenvolvimento. In: I Simpósio Mineiro de Geografia: das diversidades à articulação geográfica, 2014, Universidade Federal de Alfenas: Alfenas - Minas Gerais. Anais: Geografia Agrária, Afenas, 2014, p. 828-837. Disponível em: <

http://www.unifalmg.edu.br/simgeo/system/files/anexos/Rafaela\%20Maximiano\%20 Dantas_o.pdf >. Acessado em: abril de 2017.

ECHEVERRI, Rafael. Emergência e evolução do programa de desenvolvimento sustentável dos Territórios Curais e nos Territórios da Cidadania. In: FAVARETO, Arilson [et al] (Org.). Políticas de desenvolvimento territorial rural no Brasil: avanços e desafios. Brasília: IICA, 2010, p. 81-114.

EVANS, Peter. Para além da "monocultura institucional": instituições, capacidades e o desenvolvimento deliberativo. In: Sociologias, Porto Alegre, v. 5, n. 9, p.20-62, 2003. Disponível em: <http://seer.ufrgs.br/sociologias/article/view/5869>. Acessado em maio de 2017.

FISCHER, Tania. Poderes locais, desenvolvimento e gestão: introdução a uma agenda. In: FISCHER, Tania (Org.). Gestão do desenvolvimento e poderes locais: marcos teóricos e avaliação. Salvador, BA: Casa da Qualidade, 2002, p. 12-32.

FLORISBELO, Glauco R. Estudo propositivo da base econômica territorial: Território Médio Rio Doce. MDA/SDT, Viçosa-MG, 2005.

IBGE. Instituto Brasileiro de Geografia e Estatística - Sistema de Recuperação Automática (SIDRA). Rio de Janeiro: IBGE, 2016. Disponível em:

<https://sidra.ibge.gov.br/home/ipca/brasil>. Acessado em: fevereiro de 2017.

KAUCHAKJE, Samira. Gestão pública de Serviços sociais. Curitiba: Ibpex, 2007.

KLIKSBERG, Bernardo. A modernização do Estado para o desenvolvimento social: algumas questões chave. In: Revista de Administração Pública - RAP. Rio de Janeiro, v. 30, n. 1, p. 78-90, jan./ fev. 1996. Disponível em:

<http://bibliotecadigital.fgv.br/ojs/index.php/rap/article/viewFile/8129/6944>. Acessado em maio de 2017.

KLIKSBERG, Bernardo. Repensando o Estado para o desenvolvimento social: superando dogmas e convencionalismos. São Paulo: Cortez, 1998.

KOGA, Dirce. Medidas de cidades: entre territórios de vida e territórios vividos. São Paulo: Cortez, 2003.

LUNAS, Divina Aparecida Leonel Lunas; CARDOSO JÚNIOR, Hamilton Matos; PASSOS, Haihani Silva; GOMES, Kássia Anniély Silva. Gestão Social no Território Rural do Sudoeste Goiano: práticas e ações. In: LUNAS, Divina Aparecida Leonel, CARDOSO JÚNIOR, Hamilton Matos; GIONGO, Pedro Rogério (Orgs.). Estado e 
políticas públicas no Território Rural do Sudoeste Goiano. Goiânia: Editora Kelps, 2017, p. 81-123.

MELLO, Paulo Freire. Evasão e rotatividade em assentamentos rurais no Rio Grande do Sul. 2006. 227 f. Dissertação (Mestrado em Desenvolvimento Rural) - Faculdade de Ciências Econômicas da Universidade Federal do Rio Grande do Sul, Porto Alegre, 2006. Disponível em:

<http://www.lume.ufrgs.br/bitstream/handle/10183/7988/000563956.pdf?sequence= 1>. Acesso em: fevereiro de 2017.

MELLO, P. F. Evasão e rotatividade em assentamentos rurais no Rio Grande do Sul. 2006, 228f. Dissertação (Desenvolvimento Rural) - Universidade Federal do Rio Grande do Sul, Porto Alegre, 2006. Disponível em: Acesso em fevereiro de 2017.

ORTEGA, Antônio César. Políticas Públicas Territórios Rurais no Brasil. In: ORTEGA, Antônio César; ESTRADA, Eduardo Moyano (Orgs). Desenvolvimento em Territórios Rurais: Estudos comparados de Brasil e Espanha. Campinas: Ed. Alínea, 2015, p. 2752.

PAULA, Ana Paula Paes. Administração publica brasileira entre o gerencialismo e a gestão social. In: Revista de Administração de Empresas, São Paulo, v. 45, n. 1, p. 3649, 2005. Disponível em: <file:///D:/Assistente/Downloads/texto2.pdf>. Acessado em: fevereiro de 2017.

PORTAL DOS NEDETS. Núcleos de Extensão em Desenvolvimento Territorial. Brasília: SDT/MDA, 2015. Disponível em: <http://portaldosnedets.info/site/investimento-proinf/>. Acesso em janeiro de 2017.

REGIMENTO INTERNO. Regimento Interno do Território Rural do Sudoeste Goiano. Rio Verde - Goiás, 16 de novembro de 2010.

SANTOS, Boaventura de Souza; ALVRITZER, Leonardo. Para ampliar o cânone democrático. In: SANTOS, Boaventura de Souza (Org.). Democratizar a democracia. Rio de Janeiro: Civilização Brasileira, 2002, p. 39-82.

SANTOS, Fabiano Antônio dos. Trabalho e educação do campo: a evasão da juventude nos assentamentos da reforma agrária - o caso do Assentamento José Elias. 2006. 147 f. Dissertação (Mestrado em Educação) - Universidade Federal do Paraná, Curitiba, 2006. Disponível em:

<http://www.bibliotecadigital.unicamp.br/document/?code=vtls000045447>. Acesso em abril de 2017.

SDT. Secretaria de Desenvolvimento Territorial - Sistema de Gestão Estratégica (SGE), Brasília: SDT/MDA, 2015. Disponível em: <http://sge.mda.gov.br/sge/index.html>. Acesso em fevereiro de 2017. 
TENÓRIO, Fernando Guilherme. Gestão social: uma perspectiva conceitual. In: Revista de Administração Publica - RAP. Rio de Janeiro, v. 32, n. 5, p. 7-23, set/out. 1998. Disponível em: <http://bibliotecadigital.fgv.br/ojs/index.php/rap/art icle/viewFile/7754/6346>. Acessado em maio de 2017.

Divina Aparecida Leonel Lunas. Doutora em Desenvolvimento Econômico/Unicamp - Professora e Coordenadora do Mestrado Interdisciplinar Territórios e Expressões Culturais no Cerrado - Universidade Estadual de Goiás Bolsista do PROPIB (Programa de Incentivo à Pesquisa e Produção Científica). divalunas@gmail.com

Hamilton Matos Cardoso Júnior. Mestre em Ciências Sociais e Humanidades pelo Programa de Mestrado em Territórios e Expressões Culturais no Cerrado Universidade Estadual de Goiás; Graduado em Geografia/UEG. Atuou como Bolsista Capes e é atualmente é Técnico em Assuntos Educacionais na Universidade Federal da Paraíba (UFPB).hjuniorgo@hotmail.com 